\title{
Heave of a Building Induced by Swelling of an Anhydritic Triassic Claystone
}

\author{
Anna Ramon ${ }^{1}\left(\mathbb{0} \cdot\right.$ Eduardo E. Alonso $^{2}$
}

Received: 19 January 2018 / Accepted: 9 May 2018

(c) Springer-Verlag GmbH Austria, part of Springer Nature 2018

\begin{abstract}
This paper describes the conditions leading to a sustained, low-rate, heave phenomenon affecting a building founded on hard Keuper anhydritic rock. The building was located in an abandoned gypsum quarry. Monitoring data as well as vertical profiles of gypsum and anhydrite content indicate that swelling was associated with the presence of a shallow level of anhydritic clay rock. This paper concludes that the initial quarry excavation as well as the additional building foundation work modified the original stress state and contributed to opening fractures at depth. It also resulted in a facilitated access of water to the upper rock levels, immediately under the foundation footings. Measured heave rates are substantially lower than other rates recorded in a few recent cases. An explanation is provided for the difference. This paper describes a comforting solution for the building.
\end{abstract}

Keywords Swelling $\cdot$ Anhydrite $\cdot$ Keuper $\cdot$ Monitoring $\cdot$ Chemistry $\cdot$ Repair works

\section{Introduction}

The case described in this paper, the continuous structural damage experienced by a 23 -year-old building, presents some similarities to other civil engineering structures and buildings, reported by a number of authors during the past 15 years (Kovári and Descoeudres 2001; Amstad and Kovári 2001; Wittke 2006, 2014; Wittke et al. 2017; Anagnostou 2007; Serafeimidis and Anagnostou 2014; Serafeimidis et al. 2014; Alonso and Ramon 2013a; Ramon and Alonso 2013; Alonso et al. 2013; Ramon et al. 2017). In all the cases mentioned, the damage was induced by deep expansion in anhydritic formations. Alonso and Ramon (2013a) attributed the rock expansion to the precipitation of gypsum crystals in rock discontinuities.

Eduardo E. Alonso

eduardo.alonso@upc.edu

1 Centre Internacional de Metodes Numerics en Enginyeria, Division of Geotechnical Engineering and Geosciences, Department of Civil and Environmental Engineering, Universitat Politècnica de Catalunya, Barcelona, Spain

2 Division of Geotechnical Engineering and Geosciences, Department of Civil and Environmental Engineering, Universitat Politècnica de Catalunya, Jordi Girona 1-3, Edificio D-2, Campus Nord UPC, 08034 Barcelona, Spain
This paper describes the building structure and the observed structural damage and presents data on characteristics of the foundation material as well as measurements of structural movements and vertical strain distribution underneath the foundation recorded by field monitoring instruments. The interpretation of the observed damage and the recorded field data benefited from the previous experience in similar cases and the analysis of other well-known cases of deep heave described in the literature. The final section describes the remedial measures designed to guarantee the safety of the building.

Unlike other cases reported in the literature, the singularity of the present case history lies in the shallow origin of the observed expansion, which is attributed, in common with other experiences, to the presence of significant concentration of anhydrite. Shallow expansion phenomena associated with a previous excavation were also reported by Kleiner and Einsele (1978) and Alonso and Ramon (2015). In the first case a rapid surface heave $(15 \mathrm{~cm} /$ month) was measured after an excavation for the construction of two German motorways. These high rates decreased to slow values (a few $\mathrm{mm} / \mathrm{month}$ ) for a long period afterwards. Alonso and Ramon (2015) report the heave of a power plant foundation after a deep excavation of sulphated Tertiary claystones in Spain. The heave rate in this case also decreased from 2 to $4 \mathrm{~cm} /$ 
year at the start of measurements to about $1 \mathrm{~mm} /$ year after 3 decades of observations.

Other cases of shallow expansion of foundations reported in the literature (Hawkins and Pinches 1987a, b; Hull et al. 1980), explained also by the crystallization of gypsum, do not involve the presence of anhydrite. The swelling mechanism in these cases is explained by the oxidation of pyrites, the generation of sulphuric acid and its attack to carbonate rocks or building materials, which eventually resulted in gypsum precipitation. Pyrite was not present in the case described in this paper.

\section{Design and Construction of the Building}

The construction of the building located in the village of Corbera, Barcelona, Spain, started in 1991 and finished at the end of 1992. The building has four storeys. It occupies a rectangular area of $45 \mathrm{~m} \times 38 \mathrm{~m}$. Figure 1 shows the plan view and a representative cross section. The figure also shows that the excavation of the basement and half-basement was not uniform across the building. The heave concentrated in the zones,

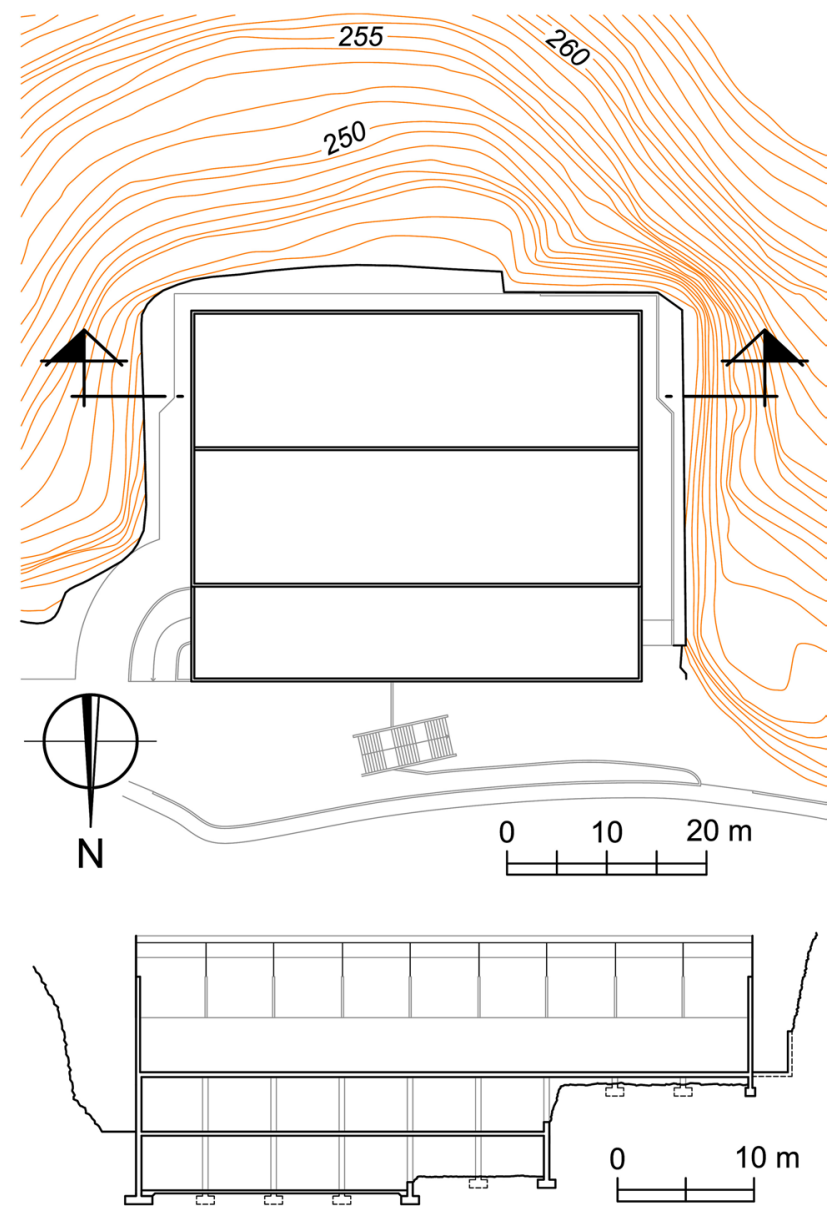

Fig. 1 Plan view and East-West representative section where the excavation depth was maximum. The structure of the two lower levels, basement and half-basement, is solved by means of columns and one-directional slabs. The perimeter wall, shown in Fig. 1, is a concrete reinforced load-bearing wall founded on a strip footing, which supports columns of upper levels.

The interior building columns are supported by isolated footings, braced among them. The footings lay at different elevations, as indicated in Fig. 1. Three foundation platforms are distinguished. Their elevation increases from East to West, as a result of the variable excavation mentioned before. The sub-vertical slopes between platforms did not present instability symptoms; they were not protected or supported by retaining walls; the natural excavated rock surface was essentially exposed.

Slopes surround the building with a high inclination facing North, East and West (Fig. 1). The construction is located in the emplacement of an ancient quarry, which mined gypsum for construction and cement manufacturing applications. The quarry was located in a Keuper rock, characterized by the presence of sulphates (gypsum and anhydrite) and clays. Keuper materials are often associated with high deformations, of tectonic origin, that contribute to their intense folding and the presence of fractures.

The construction of the building in 1991-1992 involved additional excavations over the original topography left by quarry operations. However, most of the excavation observed in Fig. 1 was already in place when the building construction started. Quarries in this type of rock often require the use of explosives for the extraction of the rock, which in turn, introduce a significant degradation and cracking in the rock mass. This comment is based on other known cases of ancient gypsum quarries in similar rock formations. However, no precise data about the quarry operation procedures are available.

The lower, half-basement and basement levels presented, at the beginning of the study described in this paper, severe cracking in the partition walls, of uncertain age. Swelling and cracking at floor level of the half-basement and basement were also observed (Fig. 2). The cracking and heave of the floor level of the basement and half-basement and the cracking observed in partition walls were very significant in the rear part of the building. In contrast, the North façade and the immediate building area did not exhibit any cracking in floors and structural slabs. The geometry of fissures suggests that damage was associated with differential vertical movements of the building foundation.

\section{Field Investigation}

Initial levelling of the floor at the position of columns of the basement and half-basement of the building, by means of precise topographic procedures in July 2014, indicated 


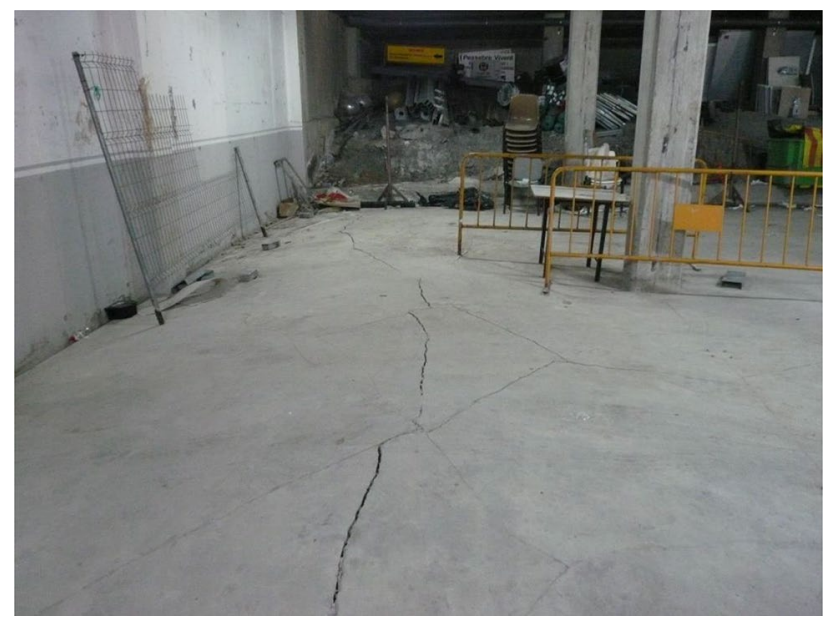

Fig. 2 Cracks and heave of the basement floor

that a non-uniform heave was developing in a large area located at the South-East side of the building (Fig. 3a). The assumption was that the builders had initially levelled the basement floor. It was further accepted that the Northern side of the basement did not experience any movement. It was also noticed that columns and the concrete floor exhibited a differential heave, which manifested in the observed network of fissures of the floor (Fig. 2).

The initial reference for the heave measurements shown in Fig. 3a was the levelling carried out in July 2014. The figure shows that the largest measured vertical displacement is located around columns $23,15,22$, and 30 and that the Northern half of the basement floor of the building exhibited very small movements if compared with the heave experienced by columns located a few meters away from the Southern wall. Measurements also indicated that the magnitude of heave decreases towards the non-excavated area of the basement and half-basement.

Geotechnical and structural investigations were initiated once the topographic levelling of basement floor had detected the development of heave in some columns. A topographic monitoring campaign for the structure was launched and the foundation material movements in depth were investigated by means of continuous extensometers installed in boreholes. The boreholes allowed also the recovery of cores and the mineralogical analyses of the foundation material.

The upper part of the columns and the perimeter lateral wall of the basement were instrumented by means of reflecting prisms. A laser-based three-dimensional control of movements provided displacements along the vertical $(Z)$ and two perpendicular horizontal directions $(X, Y)$.

Figure 4 shows the evolution of vertical movements measured in columns during 29 months in the period July 2014-December 2016. The measurements show that some columns are experiencing a slow but systematic and

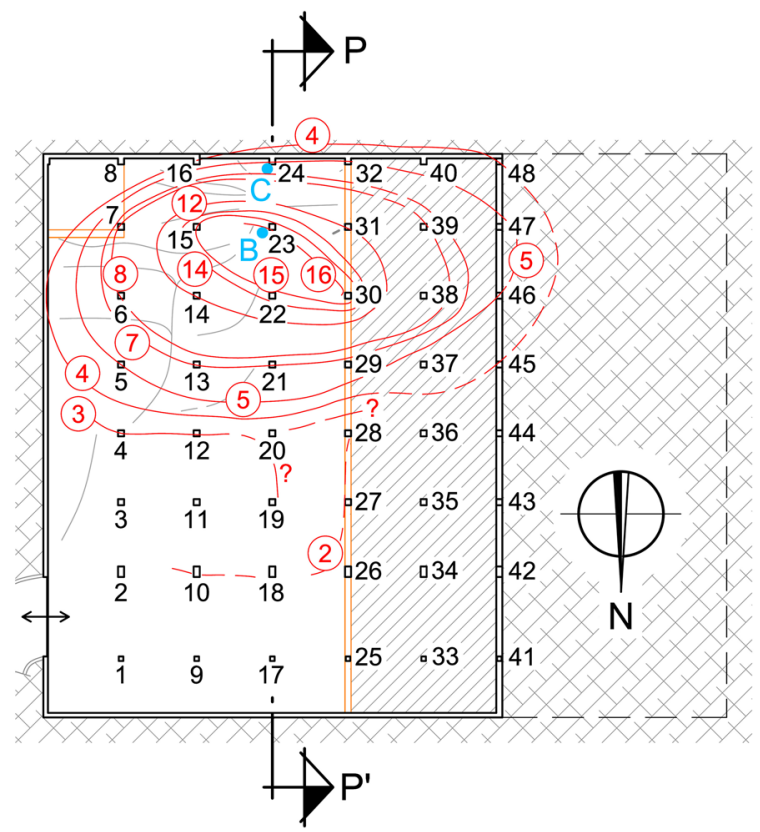

(a)

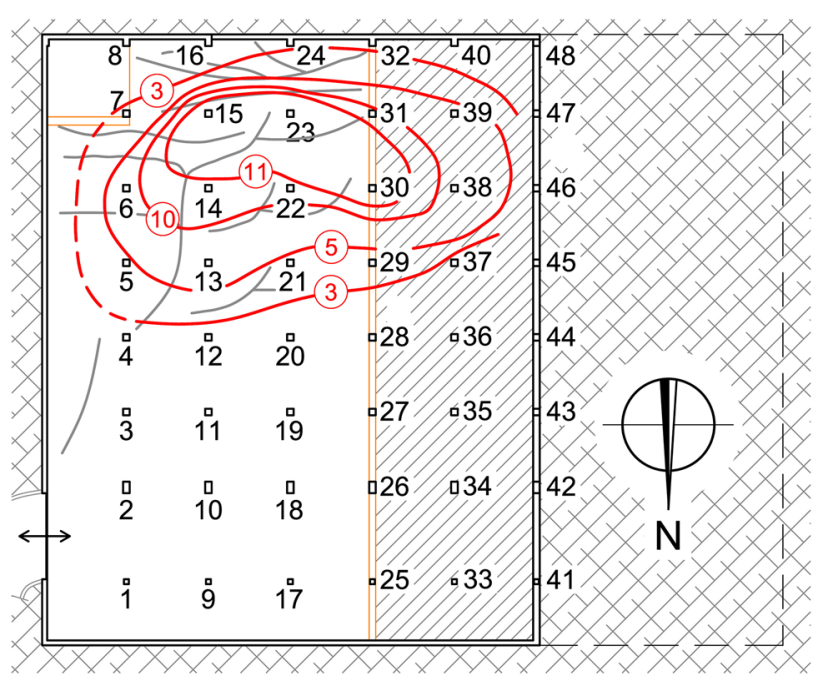

(b)

Fig. 3 a Contours of equal surface heave $(\mathrm{cm})$ of the floor of basement and half-basement estimated from topographic levelling (July 2014) and position of surveying boreholes B and C. Profile P- $\mathrm{P}^{\prime}$ is shown in Fig. 12. b Contours of equal heave $(\mathrm{mm})$ measured in the period August 2014-December 2016

continuous heave. The distribution, in plain view, of the vertical movements measured in columns during the 29 months of topographic control is consistent with the distribution of heave obtained from the initial levelling of the columns (Fig. 3b). The maximum heave recorded after 29 months of measurements was $11.8 \mathrm{~mm}$ and values close or slightly higher than $11 \mathrm{~mm}$ were measured in columns: 14 , $15,22,23,30$, and 31 . These columns are located inside 


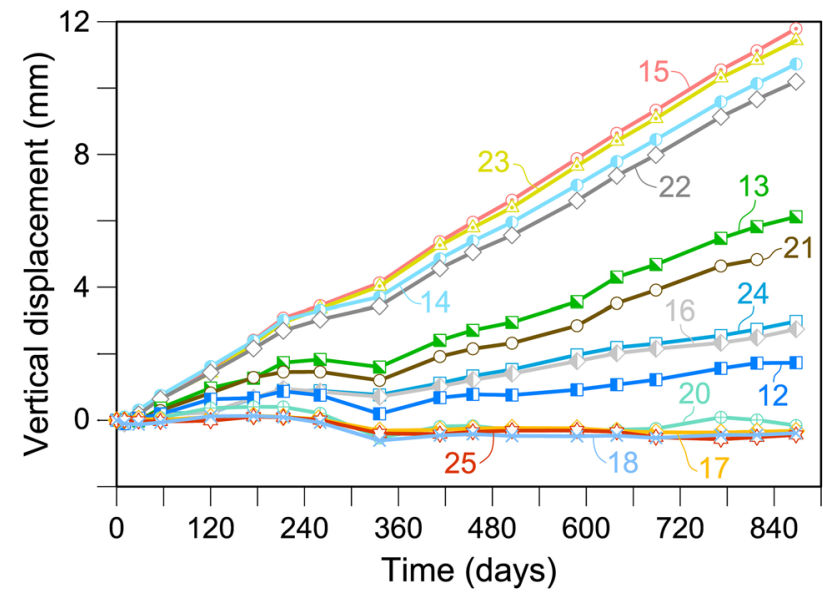

Fig. 4 Evolution of vertical movements measured in topographic marks installed on columns P12-P25 (see column position in Fig. 3)

the area were the largest heave had been measured during the initial levelling of columns.

The horizontal movements measured in the topographic marks installed in columns, along $X$ and $Y$ directions, are small. A maximum horizontal movement of $1 \mathrm{~mm}$ was measured. Measured horizontal displacements are probably a result of temperature changes and do not allow extracting clear conclusions about a horizontal ground motion.

Two boreholes $20.4 \mathrm{~m}$ long and $101 \mathrm{~mm}$ in diameter were drilled with continuous core recovery. Figure 3 a shows the position of Boreholes B and C located in the area experiencing the highest floor heave. Borehole $\mathrm{B}$ was placed next to a column that had experienced a heave of $16 \mathrm{~mm}$ after the construction of the building according to the initial levelling of pillars (Fig. 3a). Borehole $\mathrm{C}$ was drilled next to a column, belonging to the rear wall, which had suffered a small heave $(5 \mathrm{~mm})$ according to the initial levelling.

Boreholes were drilled in the vicinity of the columns with the purpose of crossing the column footings. The idea was to investigate the nature of the footing-ground contact. The two boreholes crossed, in a downwards direction, a $10 \mathrm{~cm}$ thick layer of concrete with steel reinforcement corresponding to the floor basement, a layer, $10-15 \mathrm{~cm}$ thick, fill of fine sands and a $80 \mathrm{~cm}$ thick layer of concrete without steel reinforcement, which was identified as a column footing. The recovered core indicated that the footing had been founded directly on the natural rock. The cores in the rock mass identified a sulphated rock with interbedded carbonated and grey dolomitic layers. Figure 5 shows dense accumulations of gypsum and anhydrite crystals, observed in rock cores.

The cores indicated a moderate rock cracking in the upper meters of the foundation material. Free water levels inside boreholes were monitored during and after drilling operations. A leak of water, which emptied the borehole, was detected during the drilling operations of borehole B

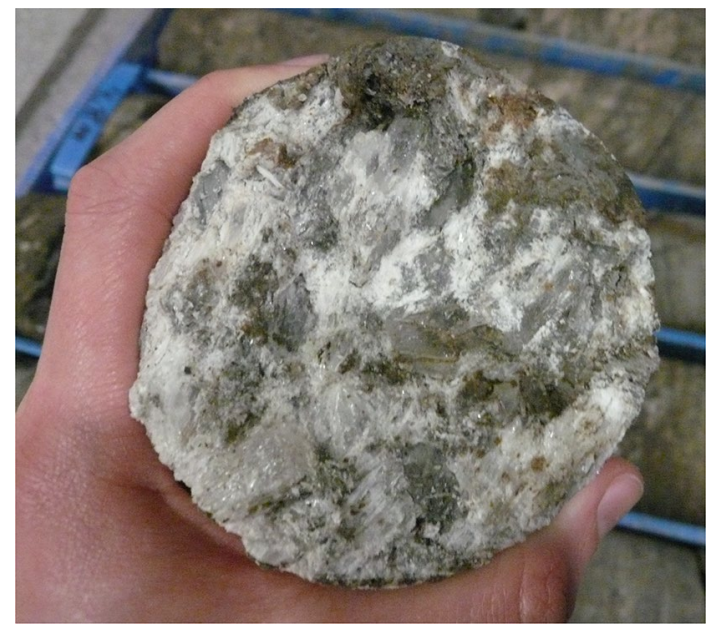

Fig. 5 Detail of crystals in a core recovered in borehole B

at a depth of 8-9 m. The recovered core in this borehole exhibited an intense cracking at those depths. In borehole $\mathrm{C}$, the leak of water was detected at a depth of 1-2 $\mathrm{m}$ and zones of cracked and weathered rock were identified in the rock cores at a depth of 4-5 m. In addition, a rise of water level was observed in the interior of both boreholes after a rainy weekend.

Both boreholes were instrumented by means of a telescopic measuring tube that allows the measurement of vertical deformations along the borehole by means of a sounding line (sliding deformeter, Solexperts AG). Figure 6 shows the incremental vertical deformations measured, in a 26-month period, in sliding deformeter SLD-01, along borehole B. Significant vertical deformations concentrate in the four upper meters.

\subsection{Water Chemistry and Rock Mineralogy}

The chemical analysis of a sample of water obtained from one borehole at Corbera foundation (Table 1; Fig. 7) shows the presence of dissolved sulphates at high concentrations in the groundwater. Also included in the Table are salt concentrations in water from Lilla tunnel (at three different chainages) (Alonso et al. 2013) and Pont de Candí Bridge (Alonso and Ramon 2013a; Ramon and Alonso 2013). A severe heave occurred in both cases. Sulphates concentration is high in all cases, specially in Pont de Candí Bridge and Corbera foundation. Unlike the other cases included in Table 1, Corbera foundation water has a high concentration in chloride salts, especially sodium chloride. This is reflected in a high electrical conductivity. The effect of salt concentrations (other than sulphates) on the saturation concentrations of water in the presence of gypsum and anhydrite was investigated with the help of program PHREEQC (Parkhurst 1995; Parkhurst and Appelo 1999). Results, plotted in Fig. 8 , 


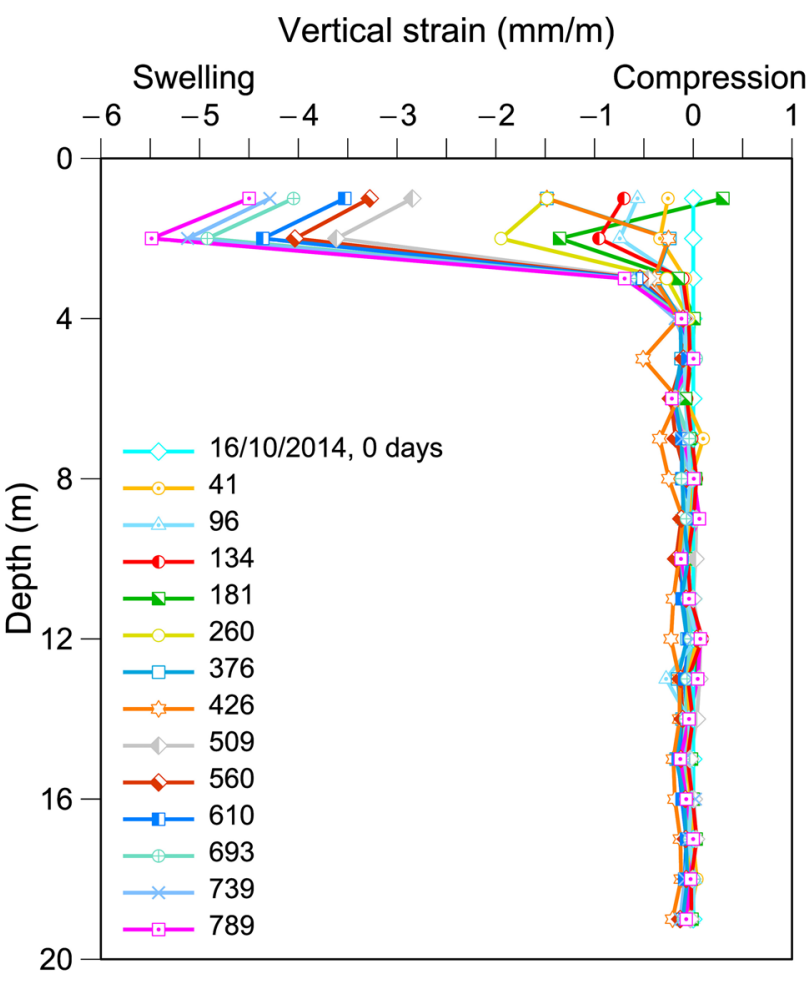

Fig. 6 Vertical strains along depth measured by sliding deformeter SLD-01 installed next to column 23 (see column position in Fig. 3)

show that increasing the salt content results in an increase of saturation concentration for both, gypsum and anhydrite. However, the "distance" between the two curves for a given salt concentration, which defines the potential precipitation of gypsum for temperatures lower than $58 \mathrm{C}$ (the temperature for the crossing between the anhydrite and gypsum curves), remains essentially constant. This result indicates that the high salt concentration in Corbera, if compared with other cases, does not seem to be a relevant condition to interpret the observed heave.

The gypsum saturation index (SI) given in Table 1 was determined by chemical analysis performed by means of PHREEQC program, which simulates chemical reactions in aqueous solutions. The saturation index (SI) compares the current chemical activities of the dissolved ions with the chemical equilibrium conditions by means of the comparison between the ion activity product, IAP, and the solubility product, $K_{\text {sp }}$ :

$\mathrm{SI}=\log _{10}\left(\frac{\mathrm{IAP}}{K_{\mathrm{sp}}}\right)$.

Saturation of a given salt is indicated by an SI value close to zero. This is the case of all the cases included in Table 1 . The results show that natural ground water presents in all the cases a very low saturation index with respect to gypsum, very close to saturation values. SI values above zero indicate supersaturation conditions. It was also found that Corbera groundwater exhibited positive SI values for calcite and dolomite.

Fifteen rock samples recovered from boreholes were subjected to X-ray diffraction analyses. The samples were recovered at intervals separated $1.5 \mathrm{~m}$ approximately. In addition,

Table 1 Chemical analysis of natural ground water collected at different sites

\begin{tabular}{|c|c|c|c|c|c|}
\hline Origin of water & $\begin{array}{l}\text { Lilla tunnel, chainage } \\
411+680 \text { (Alonso } \\
\text { et al., 2013) }\end{array}$ & $\begin{array}{l}\text { Lilla tunnel, chainage } \\
413+035 \text { (Alonso et al. } \\
2013 \text { ) }\end{array}$ & $\begin{array}{l}\text { Lilla tunnel, chainage } \\
413+050 \text { (Alonso et al. } \\
2013 \text { ) }\end{array}$ & $\begin{array}{l}\text { Pont de Candí Bridge } \\
\text { (cross-hole tests) } \\
\text { (Alonso and Ramon } \\
\text { 2013a; Ramon and } \\
\text { Alonso, 2013) }\end{array}$ & $\begin{array}{l}\text { Corbera } \\
\text { foundation (this } \\
\text { paper) }\end{array}$ \\
\hline Macro constituent & Concentration (mg/l) & & & & \\
\hline Chlorides & 39.00 & 35.55 & 38.82 & 445.34 & 1130.18 \\
\hline Sulphates & 1783.00 & 1692.00 & 1842.00 & 2475.65 & 2329.07 \\
\hline Bicarbonates & 302.00 & 301.64 & 269.76 & 174.87 & 153.37 \\
\hline Carbonates & & & & 0.00 & 0.00 \\
\hline Nitrates & 6.00 & 2.10 & 2.06 & 0.02 & 5.19 \\
\hline Sodium & 29.20 & 34.80 & 33.60 & 588.6 & 942.11 \\
\hline Magnesium & 141.00 & 144.73 & 164.23 & 160.29 & 201.04 \\
\hline Calcium & 550.00 & 603.07 & 572.94 & 535.41 & 473.10 \\
\hline Potassium & 3.20 & 4.34 & 3.01 & 10.47 & 87.28 \\
\hline $\begin{array}{l}\text { Electrical conductivity } \\
\text { at } 20^{\circ} \mathrm{C}(\mu \mathrm{S} / \mathrm{cm})\end{array}$ & 2820 & 2670 & 2640 & 4650 & 6140 \\
\hline $\mathrm{pH}$ & 6.75 & 6.78 & 7.57 & 7.16 & 7.78 \\
\hline $\begin{array}{l}\text { Gypsum Saturation } \\
\text { Index }\end{array}$ & -0.01 to -0.02 & -0.02 to -0.05 & -0.02 & 0 & -0.11 \\
\hline
\end{tabular}


Fig. 7 Chemical composition of groundwater samples collected at different locations affected by anhydrite-related expansions

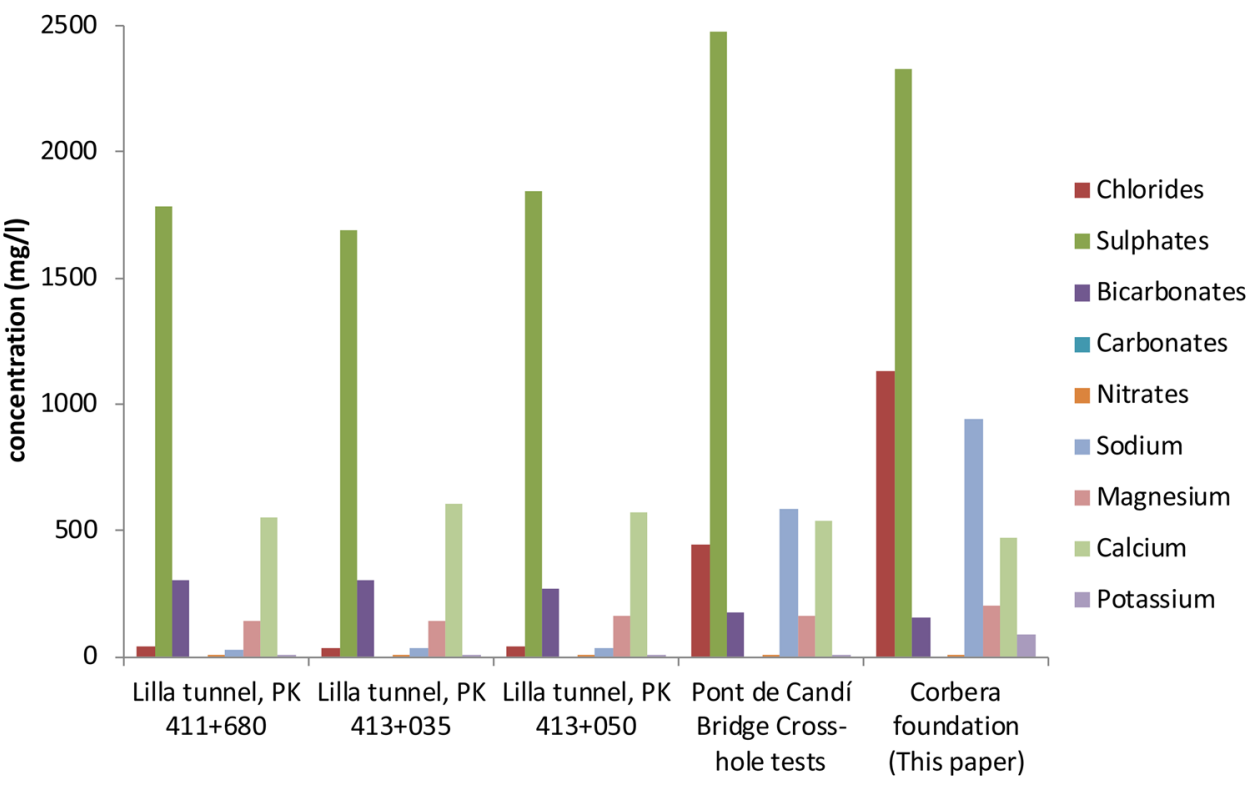

Fig. 8 Evolution of calcium sulphate equilibrium concentration with respect to gypsum and anhydrite at different temperatures in aqueous solutions with different concentrations of salts (Ramon et al. 2017)

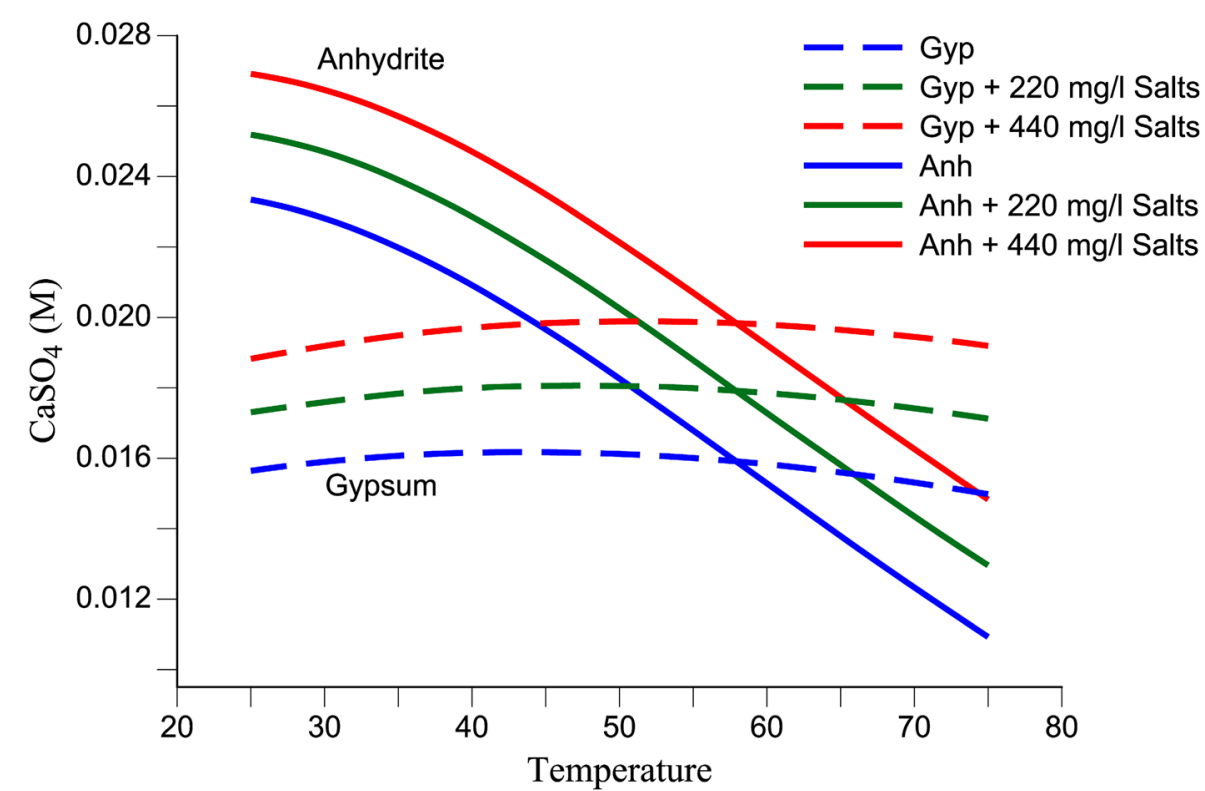

seven rock samples, collected from exposed rock outcrops at several elevations of the surface of the excavated rock slope located on the Eastern lateral side of the building were also subjected to X-ray diffraction tests.

The mineralogical compositions of all samples were determined. Anhydrite and gypsum were present in almost all the samples recovered from boreholes analysed. The amount of anhydrite detected in diffraction tests was in the range 100-16.7\% by weight. The content of gypsum (22.6-2.4\%) was significantly lower than the content of anhydrite in almost all samples. The diffraction tests also identified dolomite, magnesite, quartz (traces) and illite and montmorillonite in some samples. In contrast, the results of the diffraction tests performed in the samples obtained from the surface of the excavated slope close to the building (at depths ranging from 3 to $9 \mathrm{~m}$, with respect to the original natural surface) showed that gypsum was the most predominant mineral ( $47.5-85.7 \%$ by weight) in all the samples. Other identified mineral species, and the approximated proportions by weight of theses samples, were: magnesite (17-1.1\%), dolomite (29.0 and $9.0 \%$ in two samples), quartz (lower than 1.2\%), illite (15.8-2.8\%) and montmorillonite (3.5-8.8\%). The important result, however, is that anhydrite was not present in the exposed rock slopes at elevations above the foundation level of the building. 
Figure 9 shows, in a common depth scale, the distribution in depth of the proportion (\% by weight) of anhydrite and gypsum identified in the samples obtained from the boreholes and the excavated rock slope. The origin of the depth scale in Fig. 9 is the surface of the original natural slope before the quarry excavations. Point "O" in Fig. 12 indicates the position of the original soil surface, before quarry excavations, which is the origin for depths in Fig. 9 for the rock cores recovered in boreholes. Figure 9 points out that anhydrite is present in massive proportion in the rock mass at relatively shallow depths: $9 \mathrm{~m}$ below the natural ground surface. The figure shows the position of a sharp gypsum-anhydrite transition. Building foundations were almost exactly located at this transition front.

\section{Interpretation}

Sliding deformeters detected an "active" expanding layer in the upper 2-4 $\mathrm{m}$. The unreinforced basement concrete slab, $10 \mathrm{~cm}$ thick, does not introduce any significant restraint to the vertical expansion and it is severely cracked (Fig. 2). The cracking follows a pattern, which is explained by the "fixed" points at the position of the column footings. The levelling measurements are systematic and indicate a clear heave of the instrumented columns of the building. It is concluded that the basement floor has experienced the largest heave displacements.

Figure 4 shows that building columns experience a sustained uplift motion at a low rate $(0.013-0.004 \mathrm{~mm} /$ day $)$ which is proportional to the total displacement heave. Most probably, heave phenomenon started during quarry

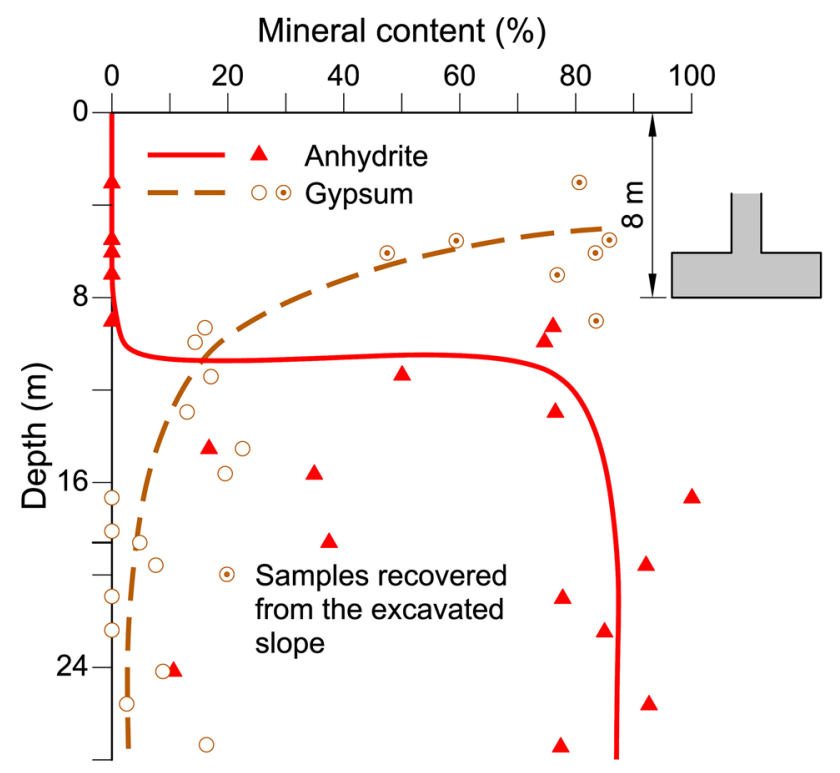

Fig. 9 Distribution of gypsum and anhydrite in depth excavation. Therefore, some heave rate was already present when building construction started, once the quarry was abandoned. Cracking and damage of walls and floors accumulated slowly during the entire building life. This permanent accumulation of damage induced by vertical heave, as well as the angular distortion between some columns or between the wall and columns (1/35-1/40), is substantially higher than the accepted limit for crack opening (1/300). This situation explains the severity of the observed cracking in the partitions of upper floors.

It was also verified that the total heave measured by standard levelling techniques at the beginning of the study, shown in Fig. 3a, display the same spatial heave pattern of column heave found when plotting the contours of equal heave after 29 months of systematic monitoring (Fig. 3b). This result shows that the set of columns experienced a continuous heave rate that has decreased slightly during the building life. The average heave rates measured during the 29 months of monitoring differ, at most, in $2.6 \mathrm{~mm} / \mathrm{year}$ from to the estimated average heave rate that occurred along 21.6 years, from the building construction to the first topographic levelling performed at the basement and sub-basement floor.

Published case histories describe several cases of severe expansion in anhydritic rock affecting engineering works and buildings. The contributions of Sass and Burbaum (2010), Kovári and Descoeudres (2001), Amstad and Kovári (2001), Wittke (2006, 2014), Wittke et al. (2017), Anagnostou (2007), Alonso and Ramon (2013a), Ramon and Alonso (2013) and Alonso et al. (2013) collect some experiences in Central Europe and Spain. The expansion phenomena in these cases occur at depth. The expansion is explained by the occurrence of precipitation and growth of gypsum crystals, which develop if (a) there is a significant proportion of anhydrite in the rock, (b) there is free water in the massif and (c) the rock exhibits some open discontinuities (Alonso and Ramon 2013a; Ramon and Alonso 2013).

Expansions are the result of precipitation of gypsum crystals from a supersaturated aqueous solution in rock discontinuities. Gypsum precipitation in fractures exerts pressure against the faces of the discontinuities, which is capable of pushing them apart and generating the swelling pressures and strains observed in the rock mass (Alonso et al. 2013; Ramon and Alonso 2013). Figure 10 sketches a conceptual representation of the development of expansion due to crystal growth in the rock mass. Gypsum crystals originate from the precipitation of calcium and sulphate ions $\left(\mathrm{CaSO}_{4}\right)$ dissolved in water supersaturated in sulphates with respect to gypsum. The solubility of anhydrite is higher than the solubility of gypsum at the temperatures existing in the rock mass. Therefore, the presence of anhydrite and water availability in the rock will provide the conditions for supersaturation, which are necessary for the precipitation of gypsum (Ramon and Alonso 2013). 


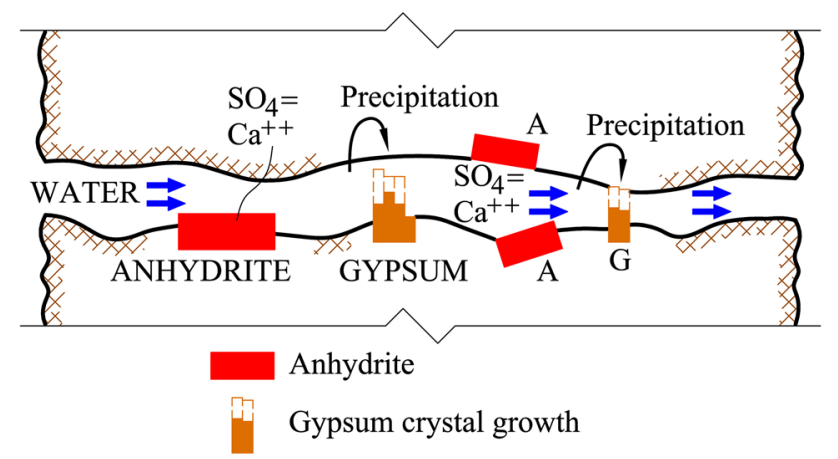

Fig. 10 Conceptual representation of gypsum precipitation on discontinuities. Ramon et al., 2017

Figure 9 shows that anhydrite was essentially absent in the upper $9 \mathrm{~m}$ of the profile. Below this depth, a very rapid increase in anhydrite content is measured. The anhydrite concentration reaches often values in excess of $70-80 \%$ and remains approximately constant with depth. In contrast, gypsum dominates in the upper 4-8 $\mathrm{m}$ and decreases continuously with depth. The resulting distribution of gypsum and anhydrite contents is similar in qualitative terms to other distributions found in cases involving deep gypsum-related heave. This was the case of Lilla tunnel (Alonso et al. 2013; Ramon et al. 2017) and Pont de Candí viaduct (Alonso and Ramon 2013a; Ramon and Alonso 2013).

The presence of gypsum is explained by the "transformation" of anhydrite into gypsum via the mechanism described above. In our case, there is a marked front for the transformation process at depths of 9-13 m. Foundation footings were resting on the natural rock at a depth of $8 \mathrm{~m}$ (Fig. 9), and therefore, the swelling process directly affected them.

The sulphate mineral distribution represented in Fig. 9 is the result of a slow reaction at the time scale of geologic processes. However, the quarry excavation and building construction activated a slow swelling mechanism (but very rapid in geological terms) because of the changes introduced: unloading, and most likely, an improved access of water to the upper anhydrite levels. The construction of the building may impair the direct infiltration of rainfall water but the evolution of free water observed in boreholes after a period of rains, during the drilling operations, indicated that water is present in the rock mass and, in addition, they suggest a reasonably high hydraulic conductivity dominated by the presence of fractures and a hydraulic connection between the building foundation rock and the outside land. Figure 11 shows the cores recovered in boreholes $\mathrm{B}$ and $\mathrm{C}$ from the upper $6 \mathrm{~m}$. The examination of the recovered cores indicated an intense disintegration at some depths. This favours the presence of water and the possibility of water circulation through the rock mass. It was concluded that the mechanism of expansion induced by the growth of gypsum crystals could develop in the rock mass located below the foundation of the building.

The applied stress on crystals controls their growth and the generation of expansive deformations and swelling pressures. This was shown when analysing the development of vertical displacements of the bridge deck and the measured strains in the active layer in Pont de Candí bridge after the construction of a confining embankment (Alonso and Ramon 2013a). The modelling of Pont de Candí bridge heave induced by gypsum crystal precipitation in the presence of anhydrite also showed a reduction on heave rate after the embankment construction (Ramon and Alonso 2013).

The excavation of the quarry implied a stress relief that is maximum at the front of the quarry (South façade of the building) and tends to disappear towards the North (Figs. 1, 12). After the excavation of the quarry, an additional excavation was performed, mainly in the area, where the heave is measured. This unloading resulted in an additional reduction of stresses.

The quarry excavation shown in Fig. 12 was probably the triggering cause of surface heave of the platform created. It reduced the confining stress of the upper levels of the rock, led to some opening of rock fissures and facilitated the access of rainfall water. Later, the building construction implied an additional smaller excavation estimated in no more than $2 \mathrm{~m}$.

Figure 12 shows the variation of the confining stress, along a horizontal plane defined by the position of the footings, due to the excavation of the quarry and the subsequent construction of the building.

The continuous footing supporting the Southern wall of the building applied an estimated stress of $200 \mathrm{kPa}$, larger than the estimated stress applied by the building isolated footings. Unlike footings, the long $(45 \mathrm{~m})$ strip load at the Southern façade is capable of maintaining a significant percentage of the applied stress in the upper levels of the supporting rock. This situation and the proximity of the excavated rock slope explain the small heave observed at the strip footing. Heave increases fast towards the first row of columns $(15,23,31 \ldots)$ and then decreases following the reduction of height of the quarry excavation towards the North façade.

The change of confining stress is a key factor to explain the heave and its distribution in plain view. The heave of the floor between columns (Fig. 2) also suggests that the stress transmitted by the column footings is effective in reducing the swelling generated by the precipitation of gypsum.

\subsection{Rate of Heave}

If compared with other known cases of anhydrite-induced swelling, measured heave rates in Corbera are small. Figure 13 shows this comparison. The heave rates of known 

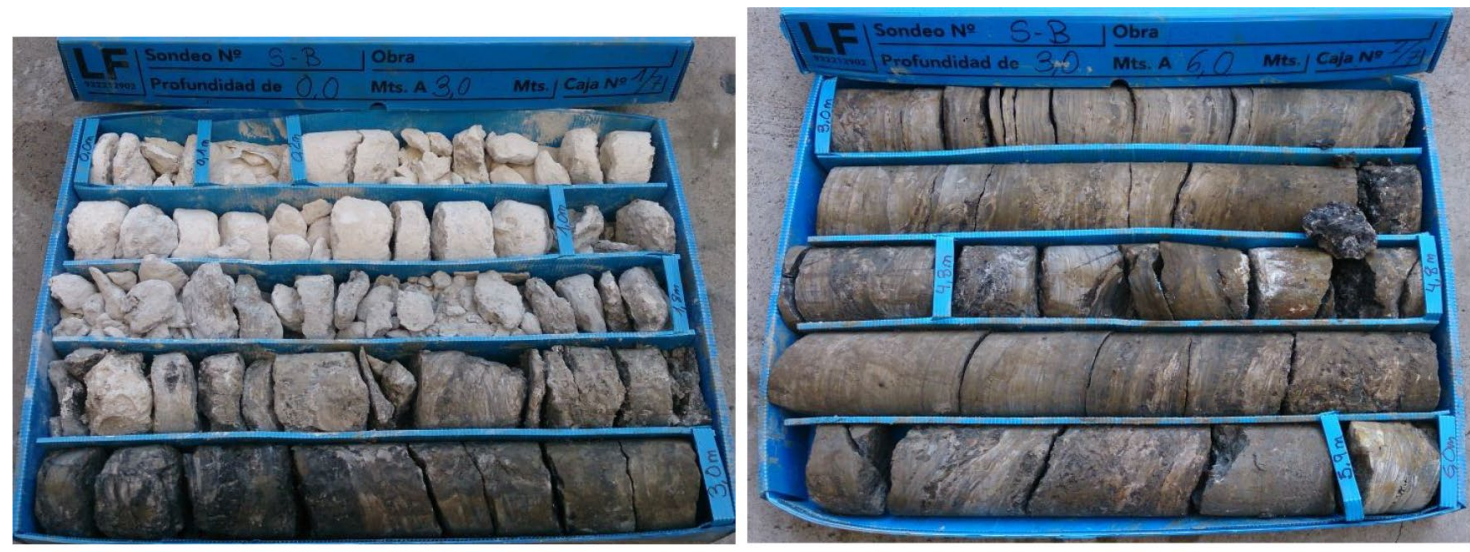

(a)
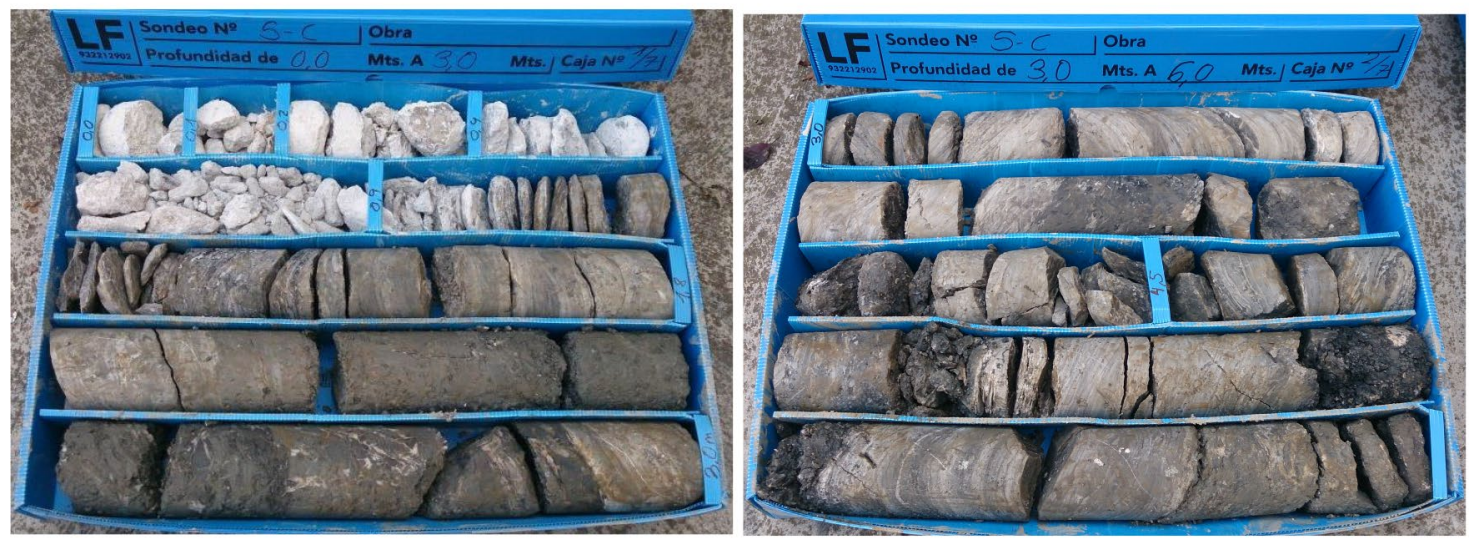

(b)

Fig. 11 Cores recovered from the six upper meters in $\mathbf{a}$ borehole B and $\mathbf{b}$ borehole $\mathrm{C}$

cases: Pont de Candí bridge (Alonso and Ramon 2013a); Lilla tunnel (Alonso et al. 2013; Ramon et al. 2017); Staufen village (Sass and Burbaum 2010; Ruch and Wirsing 2013) are significantly larger than the measured rates reported here (note the log scale of the heave rate). The plot shows the relationship between heave rate and applied effective stress at the source of swelling. The references cited describe how an increase in confining stress reduces the heave rate. Figure 13 shows also a tentative relationship illustrating the effect of stress on heave rates. However, the case described here departs from this approximate trend and shows a very small heaving rate if compared with the remaining cases represented.

Heave rates in the three reference cases in Fig. 13 were estimated at early stages, i.e., shortly afterwards the swelling process was identified. It may be argued that as time increases the swelling rate should decrease. This may be a consequence of the exhaustion of anhydrite content. In fact, Ramon and Alonso (2013) show how the calculated longterm heave, in the case of Pont de Candí Bridge, becomes asymptotic to a constant value. It may be thought that the case of Corbera due to the long history of heave estimated, since the construction of the building ( 24 years) is a case of heave rate reduction due to 'time effects'. However, it was previously argued that the heave rate has remained essentially constant during the swelling period. In addition, the anhydrite concentration remains very high in the foundation rock and the recently recorded heave records in time (Fig. 4) show an approximate linear relationship between heave displacements and time. It is concluded that the heave rates of Corbera in Fig. 13 show also the heave rate shortly after the phenomenon started, and therefore, it makes some sense to plot them in a common figure with the other cases reported.

The model for gypsum precipitation described in Ramon and Alonso (2013) shows that heave rates depend also on the kinetic law for the accumulation of gypsum and dissolution of anhydrite in time. The kinetic law depends on the evolution of sulphate concentrations in the medium and also on a kinetic constant which depends critically on the specific surface of the gypsum and anhydrite species exposed to the presence of water. Sulphate concentrations are also a consequence of details of the flow regime, and therefore, the entire 


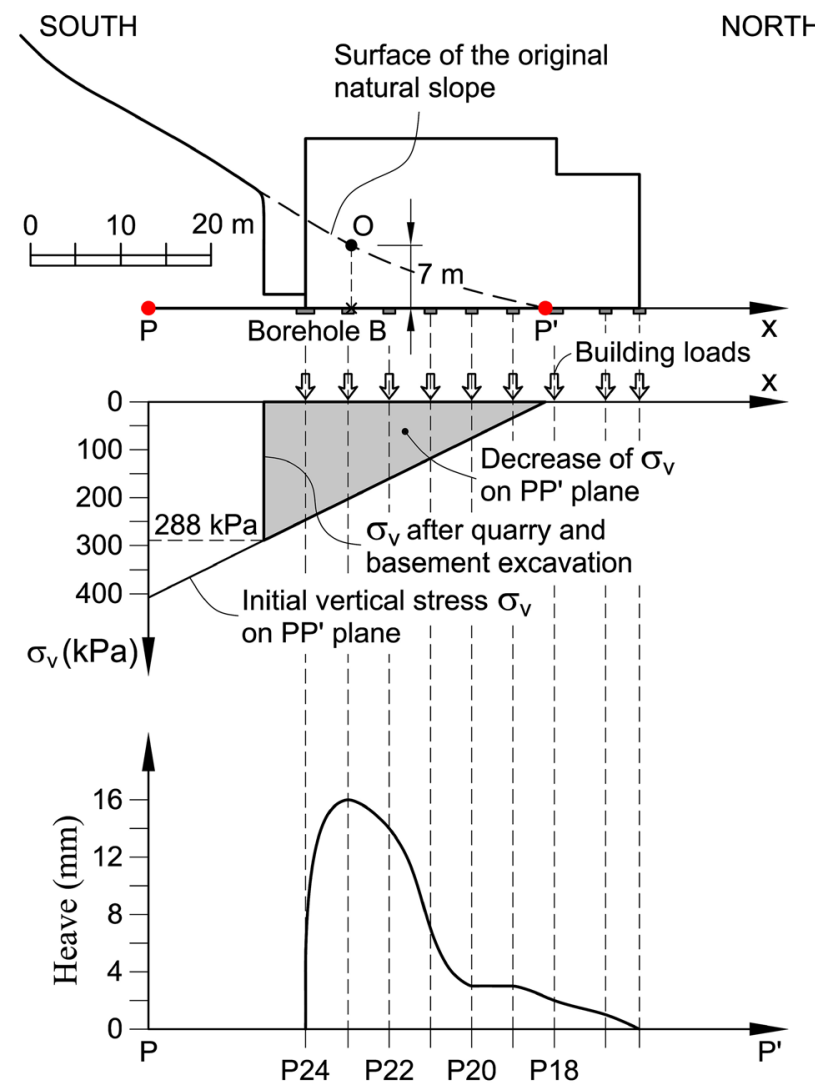

Fig. 12 Change in stress after the excavation and measured heave in July 2014

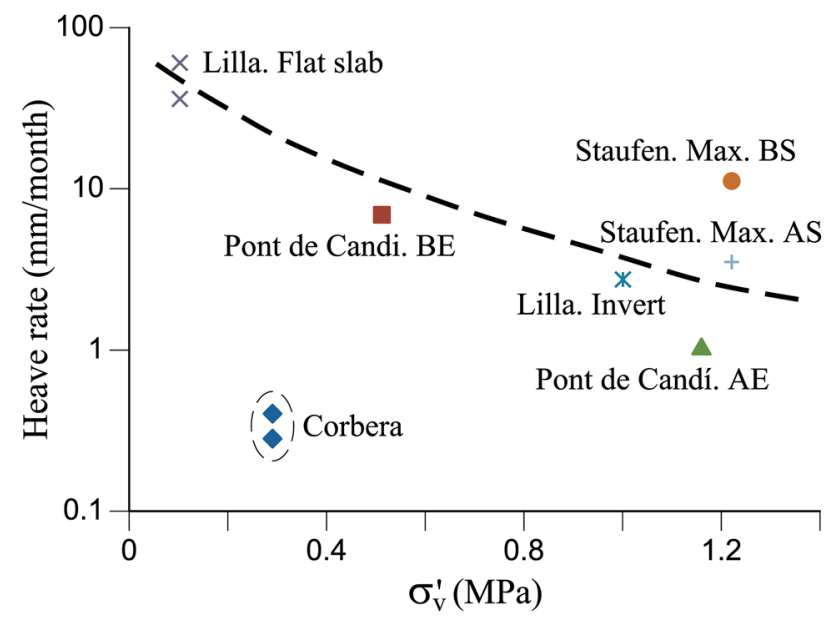

Fig. 13 Rates of heave measured in different locations. $B E$ before embankment construction, $A E$ after embankment construction, $B S$ before borehole sealing, $A S$ after borehole sealing

complexity of the case (origin and flow of water, permeability, rock microstructure) controls the heave rate. The large difference between Corbera rate of heave and the remaining cases shown in Fig. 13 suggests, in view of the preceding comments, that a combination of the following factors: difficult access to water, low overall rock permeability and a low exposed surface of anhydrite to percolating waters explain the low heaving rate observed in Corbera. Some induced fracturing or damage of the rock may also have a direct influence on the heave rate. On the other hand, the phenomenon is expected to develop during a long time under the current boundary conditions and, in particular, under the hydrological conditions of the building emplacement.

Some rock cores recovered under the foundation level were sawed and polished. Two examples are shown in Fig. 14a, b. They show the aspect of massive anhydrite. In fact, the measured anhydrite content of the cores shown in Fig. 14a, b was 100 and $76.5 \%$, respectively. This is a very impervious rock. If the observation scale is increased, to include discontinuities or clay veins, one may expect a small anhydrite surface area exposed to water dissolution. This is in sharp contrast with the anhydrite claystones identified in other cases mentioned here [Lilla tunnel (Alonso et al. 2013; Ramon et al. 2017), Pont de Candí (Alonso and Ramon 2013a; Ramon and Alonso 2013)]. In these cases, a clay matrix dominates the rock microstructure. Figure $14 \mathrm{c}$ shows one sample from the active layer in Pont de Candí bridge and Fig. 14d shows one sample from the expanding zone in Lilla tunnel. These microstructures imply a much larger exposed specific surface of anhydrite and, in addition, the clay matrix, easily fissured, facilitates the access of water. The presence of clay minerals in the foundation rock below footings 23 and 24, which experienced a significant heave (see Fig. 3a) was investigated by determining the content by weight of smectite and illite in cores from borings B and C. Results are plotted in Fig. 15. It was found that clay minerals concentrate in a band located at depths of 6-10 m below the basement floor. Above and below clay minerals were not identified. Swelling takes place in the upper $3 \mathrm{~m}$ approximately (see extensometer records in Fig. 6), where clay is absent. The minerals accompanying anhydrite above and below the clay band are magnesite and dolomite (Fig. 16). It is concluded that an additional factor, probably quite significant, to explain the low rate of heave detected in Corbera building, is the massive nature of the anhydrite, which reduces the surface exposed to water circulation. In addition, the presence of clay matrix (Pont de Candí bridge and Lilla tunnel cases) seems to favour higher swelling rates because of the clay matrix role to increase the exposed anhydrite surface to water action.

\section{Remedial Measures}

The evolution of the measured vertical displacements indicated that the heave of columns and floor of the basement and half-basement would proceed in time, essentially unchanged, in the foreseeable future. Reinforcement of the 
Fig. 14 Samples of anhydritic rock recovered from boreholes from different locations. a

Depth of sample, $9.6 \mathrm{~m}$, b depth of sample, $5.9 \mathrm{~m}$. Cuts performed on cores recovered from the foundation rock of the building in borehole B. Measured anhydrite content by weight in cores: a $100 \%$, b $76.5 \%$. c Sample of a red clay matrix with anhydrite aggregates recovered at a depth of $31.8 \mathrm{~m}$ under Pont de Candí bridge foundation: Anhydrite content: $42.2 \%$ by weight. $\mathbf{d}$ Sample of a red clay matrix with anhydrite aggregates and a gypsum vein recovered at a depth of $2.4 \mathrm{~m}$ under Lilla tunnel floor

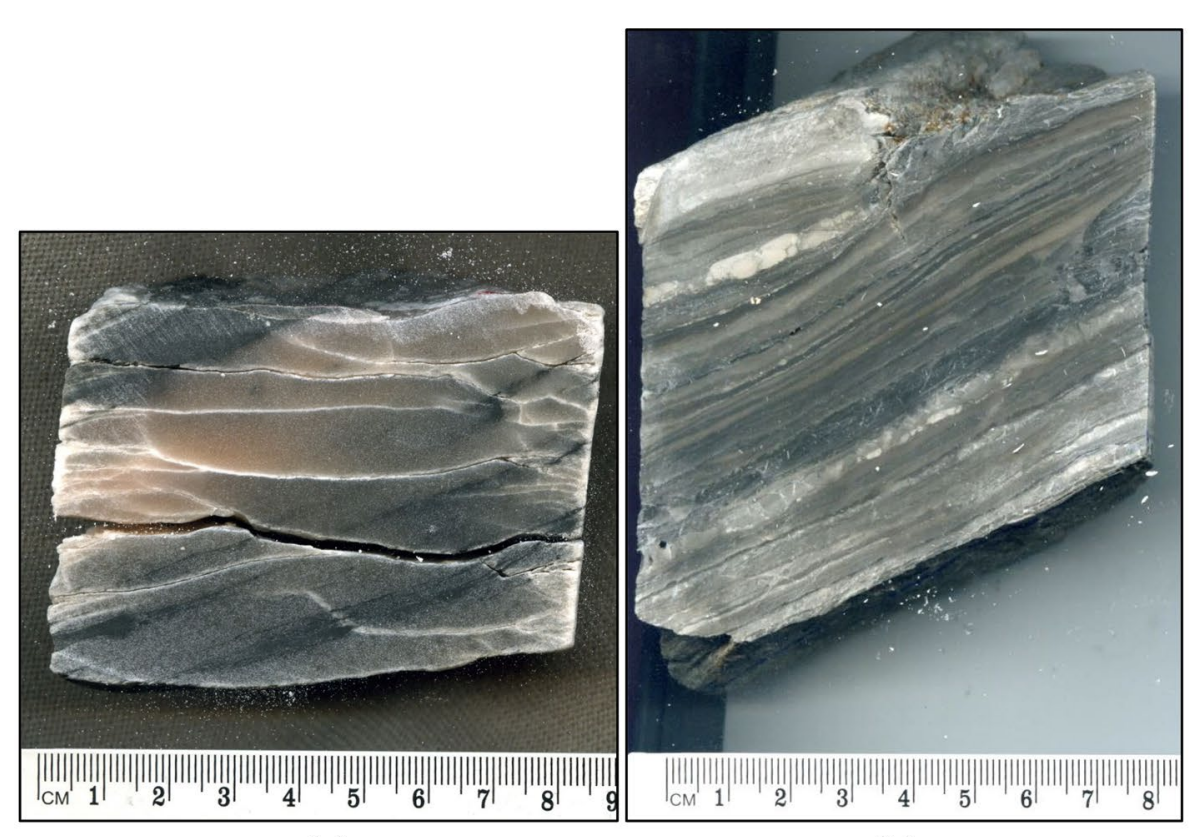

(a)

(b)
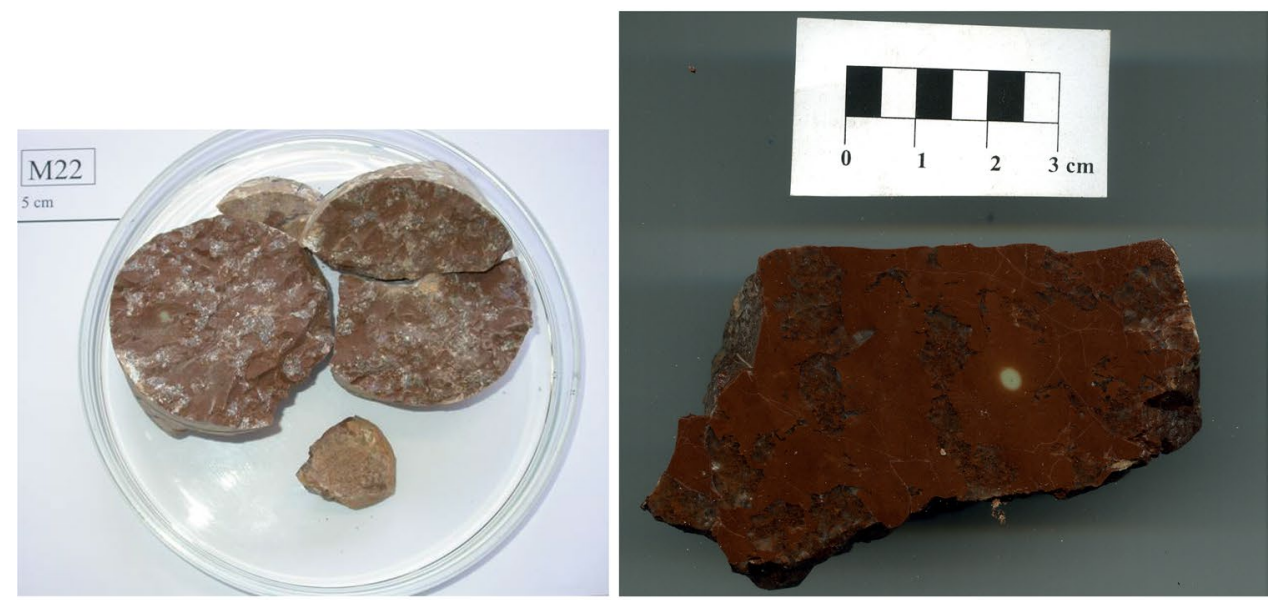

(c)

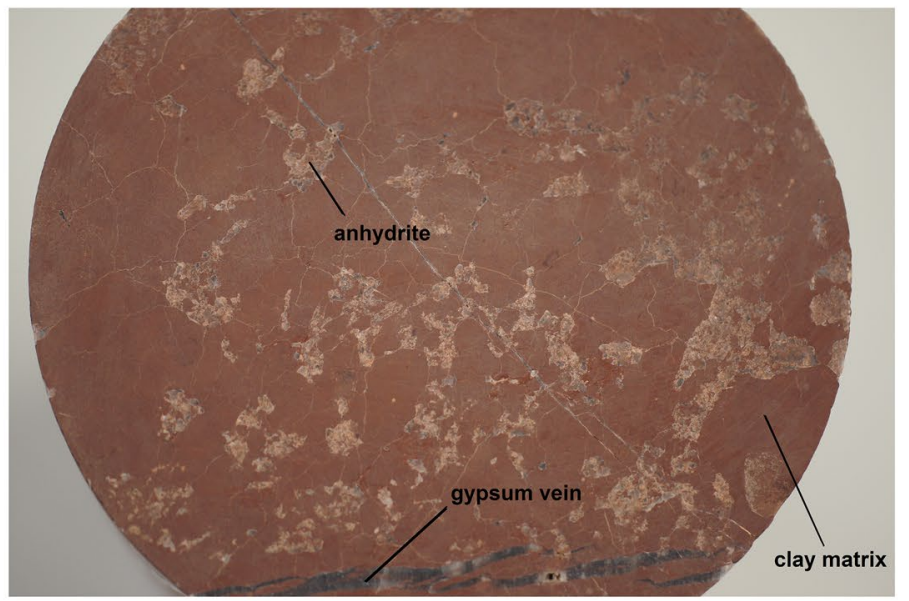

(d) 


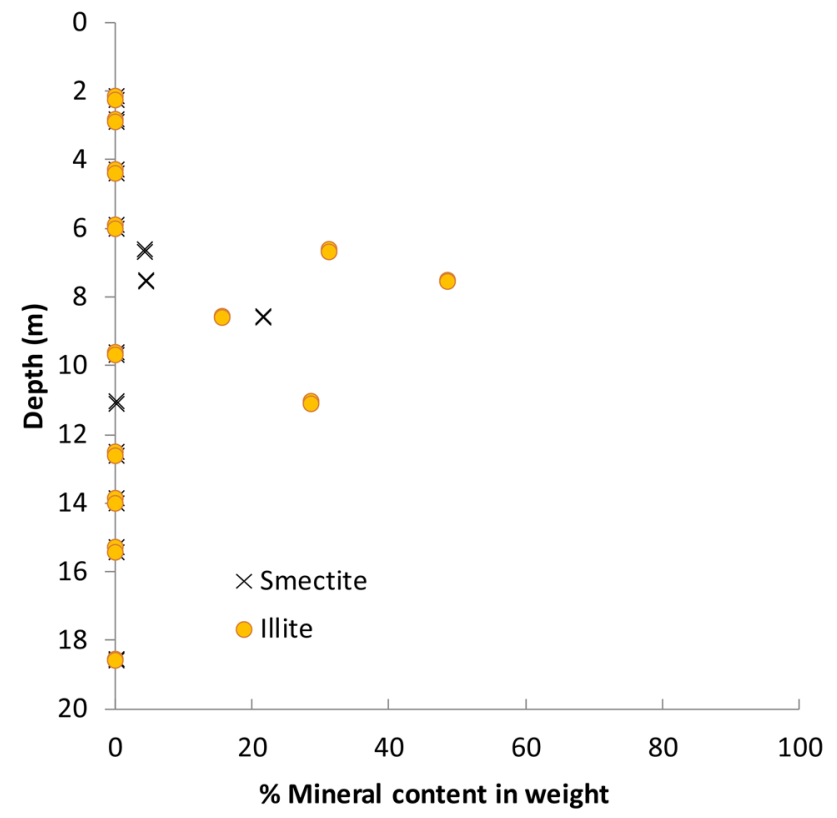

Fig. 15 Weight content of smectite and illite determined by means of $\mathrm{X}$-ray analyses in cores recovered from boreholes $\mathrm{B}$ and $\mathrm{C}$. The origin of depth corresponds to the borehole head

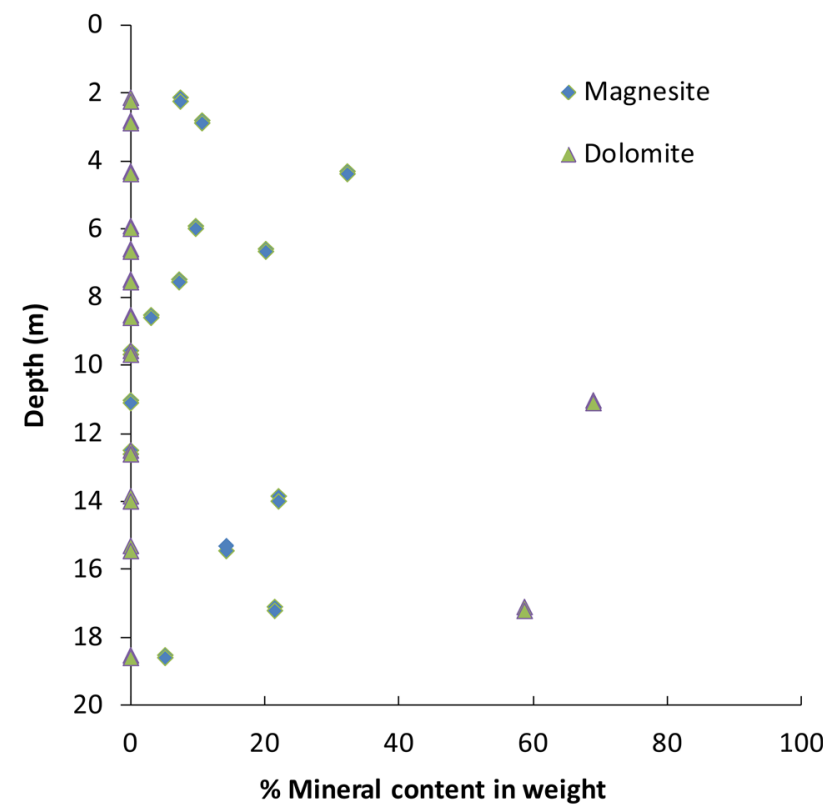

Fig. 16 Contents of magnesite and dolomite (\% by weight) determined by means of X-ray analyses in cores recovered from boreholes $\mathrm{B}$ and $\mathrm{C}$. The origin of depth corresponds to the borehole head

cracked elements of the building could not cope with the expected long-term development of expansions in the foundation material.

An underpinning of the footings supporting the columns affected by the high heave and an underpinning of the spread footing of the rear wall was proposed to protect the building against future expansions in depth.

The design of the proposed comforting solution is shown in Fig. 17. Footings are to be supported by micropiles injected at depth in zones not affected by the swelling process. The micropiles are isolated from the upper active layer, conservatively estimated to have a thickness of $6 \mathrm{~m}$, by means of a frictionless system shown in the figure. The tubular micropile is encased in a tube grouted to the rock in the upper active zone. A grease layer between the micropile and the casing eliminates any friction resulting from rock expansion. The micropiles are injected in the stable ground at depths in excess of $6 \mathrm{~m}$. The excavated rock surface along the micropiles will be sealed with grout to avoid the activation of deeper expansions (Fig. 17).

This design is based on the solution described in Alonso and Casanovas (1991). The remedial measures also called for the excavation of the ground below the footing of columns after the construction of micropiles to prevent any upwards thrust of the heaving ground against the column footings. An open gap of $10 \mathrm{~cm}$ was suggested to owners. At the current rate of average heave rate, this gap may be closed in about 20 years. Alonso and Ramon (2013b) describe a related case of isolating a railway track line against the heave of an embankment of compacted sulphated soils. Figure 18 shows two photographs taken during the construction of

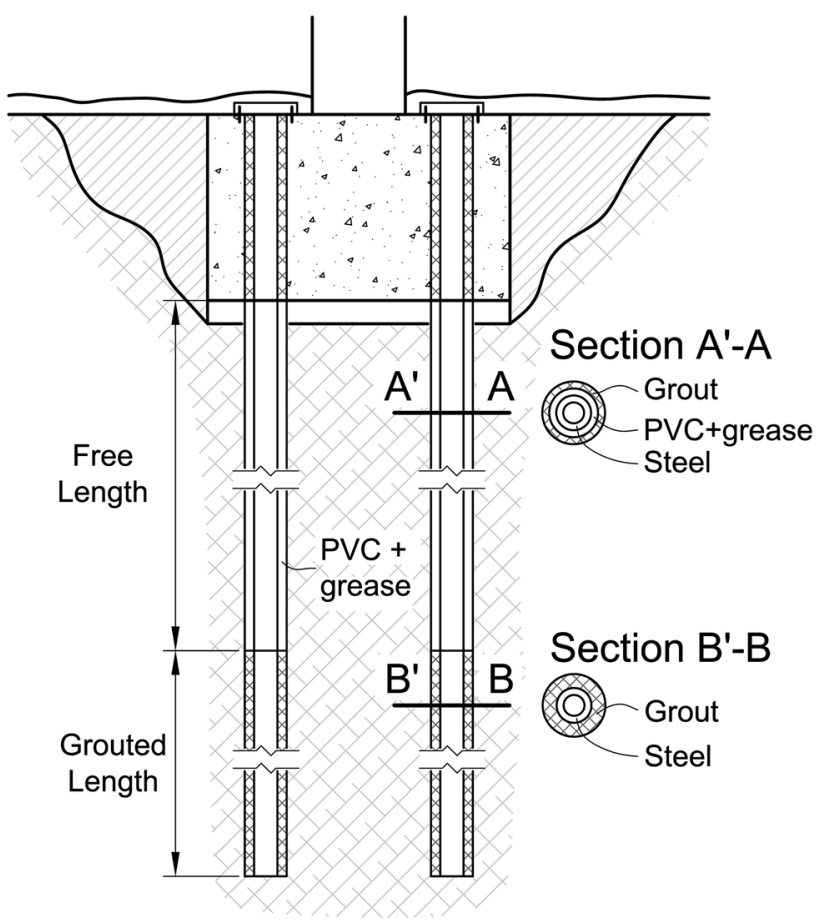

Fig. 17 Design of the micropiles with free stretch, disconnected from the ground (Alonso and Casanovas 1991) 


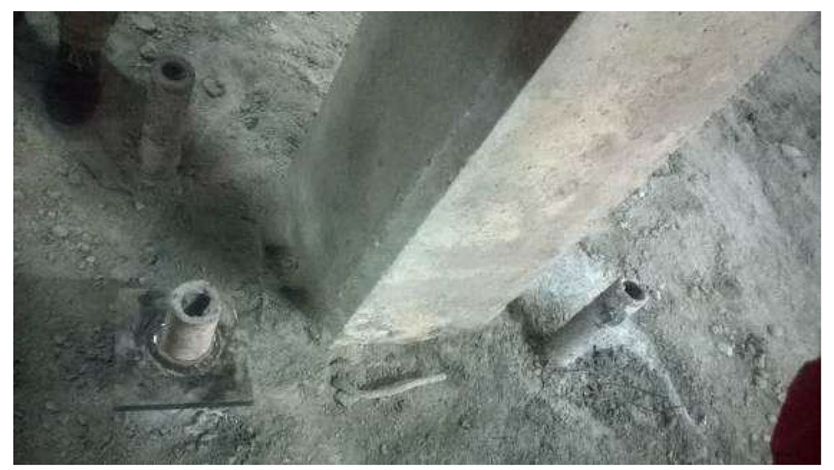

(a)

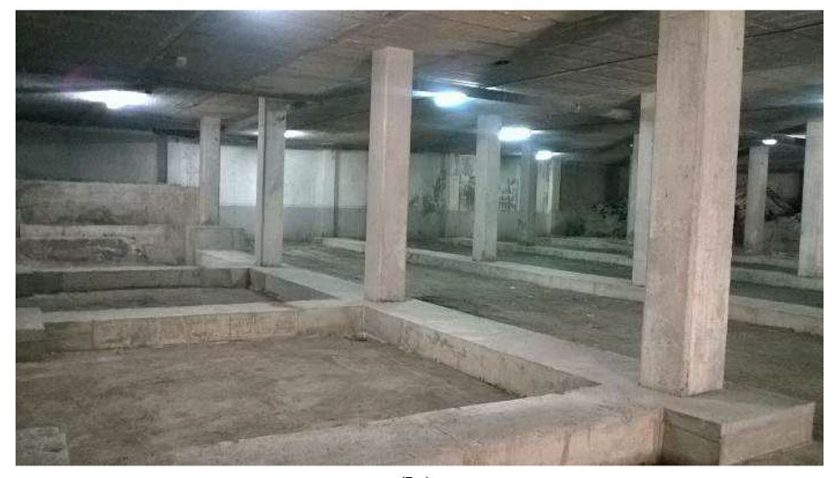

(b)

Fig. 18 Photographs taken during the construction of the works of underpinning of existing footings. a Column footing stabilized by four micropiles. b View of the building basement after repair works

micropiles for the underpinning of footings of the building columns.

\section{Conclusions}

The case described in this paper is rather singular because of the shallow depth of the active layer, identified by continuous extensometers. This, in turn, is a consequence of the shallow presence of an anhydritic Keuper claystone having a very high anhydrite content. In other known cases reported in the literature, anhydrite is buried at depth and foundations lay on gypsum-laded sediments, which do not result in heaving mechanisms.

The building was built in 1992 and it experienced a sustained heave rate, which affected to a reduced area of the building extension in plain view. This heterogeneous heave resulted, over the years, in large angular distortions (1/35-1/40 is the maximum value estimated in 2017) which explains the severe damage observed in parts of the building.

Since some building columns did not experience any heave, a topographic levelling provided an estimation of heave experienced by columns in the damaged zone. The investigation performed in 2014-2016, reported here, provided precise data on current heave rates, which are believed to be nearly constant if the recent heave records are consistent with the long-term (24 years) heave estimations.

The foundation material is an anhydritic rock of Keuper age with a massive presence of anhydrite at shallow depths. The precipitation of gypsum in fractures of the rock mass explains the heave displacements of the inner columns of the building and the heave of the floor of the basement and halfbasement. The original excavation of the gypsum quarry and the subsequent additional excavation for the construction of the building, together with the presence of water in the rock and the unloading-related opening of fissures in the foundation material, triggered the process of expansion. The pattern of stress relief and its spatial distribution support this mechanism.

A comparison of measured heave rates, and its reduction with applied stress of a few recent cases well documented as well as the present case shows that Corbera heave rate was more than one order of magnitude slower than the rest of known cases. However, the sulphate concentration in water was close to the maximum measured in all the cases compared. The anhydrite proportion in the foundation rock was also extremely high in Corbera foundation. A comparison of the microstructure of the involved rocks suggests that the exposed surface of anhydrite against water flow was low in Corbera. On the contrary, the scattered distribution of anhydrite in a clay matrix, found in other more active anhydritic claystones leads to a higher specific surface of anhydrite disseminated in a clay matrix, which favours the contact with water.

The unlimited availability of anhydrite in the foundation rock and the presence of water suggest that expansions and heterogeneous heave would probably take place for a longterm period. A comforting solution for the building under the expected future heave has been designed by means of a micropile underpinning, which ensures a lack of connection between the micropiles and footings and the shallow expansive active "layer".

Acknowledgements The authors thank Dr. E. Tauler from the Crystallographic Department of the Universitat de Barcelona for her contribution to the identification of minerals. The collaboration with the architects R. Brufau and C. Gil and the Àrea Metropolitana de Barcelona is also acknowledged. The company Soldata installed the field instrumentation and provided the monitoring data included in this paper.

\section{References}

Alonso EE, Casanovas JC (1991) Micropile foundation of a singular building over existing underground structures. In: Proc. Fondations profondes. Presse de l'École Nationale des Ponts et Chaussées, Paris, pp 93-102 
Alonso EE, Ramon A (2013a) Heave of a railway bridge induced by gypsum crystal growth: field observations. Géotechnique 63(9):707-719 https://doi.org/10.1680/geot.12.P.034

Alonso EE, Ramon A (2013b) Massive sulfate attack to cement-treated railway embankments. Géotechnique. https://doi.org/10.1680/ geot.SIP13.P.023

Alonso E, Ramon A (2015) Clay hydration and crystal growth in expansive anhydritic claystone. In: The Ascó Power Plant case. Geophysical Research Abstracts 17, EGU2015-4026, EGU General Assembly. Vienna

Alonso EE, Berdugo IR, Ramon A (2013) Extreme expansive phenomena in anhydritic-gypsiferous claystone: the case of Lilla tunnel. Géotechnique 63(7):584-612. https://doi.org/10.1680/ geot.12.P.143

Amstad C, Kovári K (2001) Untertagbau in quellfähigem fels. Eidgenössisches Departement für Umwelt, Verkehr, Energie und Kommunikation (UVEK). Bundesamt für Strassen (ASTRA), Zürich

Anagnostou G (2007) Design uncertainties in tunnelling through anhydritic swelling rocks. Felsbau 27(4):48-54

Hawkins AB, Pinches GM (1987a) Cause and significance of heave at Llandough Hospital, Cardiff-a case history of ground floor heave due to gypsum growth. Q J Eng Geol Hydrogeol 20(1):41-57

Hawkins AB, Pinches GM (1987b). Sulphate analysis on black mudstones. Géotechnique 37(2):191-196

Hull AB, Cody RD, Green SA (1980) Minimization of building heave by chemically inhibiting gypsum-induced shale expansion; a preliminary report. In: 21st U.S. Symposium on Rock Mechanics (USRMS), 27-30 May, Rolla, Missouri

Kleinert K, Einsele G (1978) Sohlhebungen in Straßeneinschnitten in anhydritführendem Gipskeuper. - Ber. 3. nat. Tag Felsmech, 9 Abb.; Aachen (DGEG), pp 103-124

Kovári K, Descoeudres F (2001) Tunnelling Switzerland. Swiss Tunnelling Society, Swiss. ISBN:3-9803390-6-8

Parkhurst DL (1995) User's guide to PHREEQC-A computer program for speciation, reaction-path, advective-transport, and inverse geochemical calculations, Water-Resources Investigations Report 95-4227. US Geological Survey, Denver

Parkhurst DL, Appelo CAJ (1999) User's guide to PHREEQC (version 2)-A computer program for speciation, batch-reaction, one-dimensional transport, and inverse geochemical calculations, Water-Resources Investigations Report 99- 4259. US Geological Survey Earth Science Information Center, Denver

Ramon A, Alonso EE (2013) Heave of a railway bridge: modelling gypsum crystal growth. Géotechnique 63(9):720-732. https://doi. org/10.1680/geot.12.P.035

Ramon A, Alonso EE, Olivella S (2017). Hydro-chemo-mechanical modelling of tunnels in sulfated rocks. Géotechnique 67(11):968982. https://doi.org/10.1680/jgeot.SiP17.P.252

Ruch C, Wirsing G (2013) Erkundung und Sanierungsstrategien im Erdwärmesonden-Schadensfall Staufen i. Br (Exploration and rehabilitation strategies in case of damaging geothermal heat exchangers in Staufen i. Br. Geotechnik 36(3):147-159

Sass I, Burbaum U (2010) Damage to the historic town of Staufen (Germany) caused by geothermal drillings through anhydrite-bearing formations. Acta Carsologica 39(2):233-245

Serafeimidis K, Anagnostou G (2014) On the crystallisation pressure of gypsum. Environ Earth Sci 72:4985-4994

Serafeimidis K, Anagnostou G, Vrakas A (2014) Scale effects in relation to swelling pressure in anhydritic claystones. In: International symposium on geomechanics from micro to macro, Cambridge, pp 795-800

Wittke W (2006). Design, construction, supervision and long-term behaviour of tunnels in swelling rocks. In: Proc Eurock 2006, Van Cotthen, Charlier, Thimus, Tshibangu eds, Taylor, Francis Grup, London, pp 211-216

Wittke W (2014) Rock mechanics based on an anisotropic jointed rock model (AJRM). Ernst, Sohn, Berlin

Wittke W, Wittke M, Wittke-Gattermann P, Stoffgesetz EC (2017) Berechnungsverfahren, felsmechanische Kennwerte und Ausführungsstatik für Tunnel im anhydritführenden Gebirge. Vortrag anlässlich des 3. Felsmechanik- und Tunnelbautages im WBICenter am 11.05.2017, WBI-Print 20, Weinheim

Publisher's Note Springer Nature remains neutral with regard to jurisdictional claims in published maps and institutional affiliations. 